\title{
Physiological and Pathological Alterations in the Mammary Gland of Holstein Cows during Transition Period
}

\author{
Jean Silva Ramos' ${ }^{1}$ Karina Medici Madureira², Vinicius Alvim Passos Baldacim ${ }^{1}$, Cynthia Pereira da Costa e Silva ${ }^{1}$, \\ Mailson Rennan Borges Dias', Cláudia Regina Stricagnolo' \& Viviani Gomes'
}

\begin{abstract}
Background: Physiological and immunological adaptations occurred in peripartum period may be responsible for susceptibility to intramammary infections during colostrogenesis. Increase in blood flow and hormones cause physiological edema by accumulation of lymphatic fluid in interstitial space. Specific composition of mammary secretion increases the susceptibility to mastitis. So, the study of physical, cellular and microbiological changes in the mammary gland in this period are fundamental for understanding, diagnosing and adopting prophylactic measures for bovine mastitis. This study aimed to characterize physiological and pathological changes that occur in the mammary gland during transition period. Materials, Methods \& Results: Thirteen cows, in second to fourth lactation were followed from 3 weeks pre-calving to 3 weeks post-calving. Cows were submitted weekly to physical examination of mammary gland, strip cup test, California Mastitis Test (CMT), Microscopic Somatic Cell Count (MSCC), and bacteriological examination of mammary secretion. Mammary quarters were divided into two groups: BAC: samples that did not present bacteriological growth throughout transition period; $\mathrm{BAC}^{+}$: samples that presented bacteriological growth in at least two isolates of the same bacterial genus. Regarding physical examination of mammary gland, the parameters localized or generalized alteration in volume, asymmetry, reddish color, reduced skin elasticity, increased temperature, and swollen consistency presented higher frequencies in the $\mathrm{BAC}^{-}$group. On the other hand, infection in mammary quarters of cows from $\mathrm{BAC}^{+}$group promoted a decrease in frequencies of increased volume, decreased elasticity, and elevated temperature in the mammary gland, in addition to a higher positivity to CMT and higher cellularity. Overall rate of intramammary infection was $25.82 \%$, with non-aureus Staphylococci (NAS) being the predominant agent (69.2\%). Maximum peak of bacterial isolates occurred immediately after calving $(33.3 \%)$. Differences were observed between groups $(P=0.021)$ for CMT, showing a higher frequency of positive tests in $\mathrm{BAC}^{+}$group (36.5\%) compared to BAC ${ }^{-}$group $(18 \%)$. MSCC varied between weeks $(P=0.001)$, groups $(P=0.001)$, and between the interaction of the two variables $(P=0.019)$. Highest median value of MSCC was observed at calving $\left(1.5 \times 10^{6}\right.$ cells $\left./ \mathrm{mL}\right)$, being different $(P=0.001)$ from the $+1,+2$, and +3 weeks and the lowest median value of MSCC $\left(0.08 \times 10^{6}\right.$ cells $\left./ \mathrm{mL}\right)$ was observed in +3 compared to previous weeks $(P<0.05)$.

Discussion: NAS was predominantly isolated in mammary secretions of cows during peripartum, it is commonly found in the skin and canal of the teat and are associated with subclinical mastitis. Peak of mammary infection was observed on calving, probably by the cortisol peak resulting in a stress leucogram and decrease in the functional activity of immune cells. Changes observed in the physical examination of mammary gland of cows from BAC group are compatible with physiological edema caused by circulatory changes that occurs with the proximity of calving, increasing blood flow necessary for production of colostrum. Alterations in the mammary quarters of cows from $\mathrm{BAC}^{+}$group may be associated with functional loss of mammary parenchyma or persistent infectious process, characterizing clinical findings of pathological changes during transition period. Mammary quarters of the $\mathrm{BAC}^{+}$group presented higher percentages of positive reactions to CMT in weeks +1 and +2 , and higher MSCC values and are associated with infection of the mammary gland.
\end{abstract}

Keywords: edema, intramammary infection, peripartum, physical examination. 


\section{INTRODUCTION}

Mammary gland of cows can undergo successive renovations during cycles that comprise lactation: lactogenesis I (growth, differentiation and colostrogenesis), lactogenesis II (full lactation) and involution (non-lactating state). In lactogenesis I gestation induces changes in endocrine system responsible for proliferation of the mammary parenchyma [14] and IgG1 are transported by mammary epithelial cells through transcytosis four weeks before calving until calving [2].

Increase in blood flow and action of hormones involved in lactogenesis I cause accumulation of lymphatic fluid in interstitial space, promoting physiological edema in udder, making it more susceptible to physical damage [12].

Composition of colostrum and transitional milk are also unfavorable to defense system of mammary gland during peripartum, increasing the susceptibility to mastitis. Despite large number of somatic cells present in these secretions, there is a low proportion and reduced viability of neutrophils [4]. Predominant IgG1 in colostrum does not contribute to phagocytosis of bacteria by polymorphonuclear cells due to its low opsonizing activity [5].

Colostrogenesis may be a risk phase for mastitis in immediate postpartum and it is extremely difficult to differentiate physiological from pathological edema of udder, due to the similarity of clinical signs and inviability of tests that estimate the cellularity of mammary secretion in this period [17]. The aim of this study was to characterize physiological and pathological alterations in mammary gland of Holstein cows during transition period.

\section{MATERIALS AND METHODS}

\section{Animals and conditions of study}

The study was conducted between September and November on an experimental farm belonging to the Paulista Agency of Agribusiness Technology (APTA) located in the city of Nova Odessa - São Paulo, Brazil (latitude $22^{\circ} 75^{\prime} \mathrm{S}$ and longitude $47^{\circ} 27^{\prime} \mathrm{W}$ ). Thirteen Holstein cows were selected, between second and fourth lactation, according to the date of insemination and calving prediction. Cows were monitored weekly at seven different times during the transition period, including calving (week -3 to week +3 ), and were submitted to physical examination of the mammary gland
( $\mathrm{n}=52$ mammary quarters, 364 evaluations, weeks -3 to +3 ), examination of mammary secretion that included strip cup test ( $n=156$ samples, weeks +1 to +3 ), California Mastitis Test - CMT ( $\mathrm{n}=156$ samples, weeks +1 to +3$)$, microscopic somatic cell counts $-\operatorname{MSCC}(n=$ 208 samples, from calving to +3 ), and bacteriological examination ( $n=364$ samples, weeks -3 to +3$)$.

Management procedures adopted during study were according to farm routine, including dry cow therapy using a product (Mastijet fort) ${ }^{1}$ containing the antimicrobials tetracycline $(200 \mathrm{mg})$, neominine (250 mg), and bacitracin (2000 IU) with $10 \mathrm{mg}$ of prednisolone.

Cows were transferred to the maternity pen composed of Cynodon grass, 30 days before the expected calving. Regarding the welfare conditions, the absence of coverage was verified; except for the existence of some trees, there were no specific areas for parturition and the deliveries were not attended at night. After calving, animals were transferred to paddocks for newly calved cows and separated in batches according to dairy production.

Composition of the diet offered to cows during pre and postpartum was the same; however, the amounts of corn silage (prepartum: $20 \mathrm{~kg}$, postpartum: $35 \mathrm{~kg}$ ) and concentrate (prepartum: total equivalent to $3 \mathrm{~kg}$, postpartum: $1 \mathrm{~kg}$ for each liter of milk produced) were different. The anionic balance of diet was not considered due to low rates of occurrence of hypocalcemia and retained placenta. Drench postpartum was also not provided.

Physical examination of the mammary gland was performed in a containment trunk, according to Grunert [8]. All mammary quarters were examined by inspection and palpation. Parameters used in the physical examination are presented in Table 1.

\section{Samples and parameters}

After physical examination, the cows were transferred to milking parlor in order to ensure the hygiene of the samples for bacteriological examination. Teats were predipped with $2 \%$ sodium hypochlorite solution and dried with individual paper towels; then the first mammary secretion jets were discarded for the strip cup test.

For bacteriological examination, $3 \mathrm{~mL}$ of mammary secretion was obtained in sterile plastic bottles with screw caps, after disinfecting teats with $70 \%$ alcohol [9] and it was performed according NMC [14]. 
Samples were considered to have an intramammary infection (IMI) if they had three or more colonies of the same type. Samples with three or more species on a plate were considered contaminated. If no bacterial growth was observed after $72 \mathrm{~h}$ on the initial culture the incubated sample was replated.

California Mastitis Test (CMT) and Microscopic Somatic Cell Count (MSCC) were performed from parturition. For CMT, samples with negative or traces results were considered negative because of the high cellularity expected for this phase of lactation, whereas $1+$ to $3+$ reactions were considered positive [21]. For MSCC, $50 \mathrm{~mL}$ of mammary secretion was obtained in conical plastic tubes [6].

Mammary quarters that did not present bacterial isolation at any of the study times $(-3$ to +3$)$ were included in the BAC $^{-}$group, while those with at least two isolates of the same bacterial genus were grouped in the $\mathrm{BAC}^{+}$group.

\section{Statistical analysis}

Statistical analysis was performed using the Statistical Social Package Science program - version 18. Variables of the study were qualitative (binary and ordinal) and quantitative. Generalized estimating equations (GEE) from a generalized linear model (GLM) was used with a logistic model for qualitative binary and ordinal variables. The quantitative MSCC variable was tested for the type of distribution and adjusted for the best model according to the Akaike information criterion (AIC). For the latter, the model of distribution Gama on the GEE was adopted. Time and group were the predictor variables tested for effect and interaction. In the definition of the model, exponential parameters were proposed to obtain odds ratio (OR) and confidence interval.

\section{RESULTS}

During the study, some samples were discarded due to insufficient volume and manifestation of disease (ketosis) in three cows. In addition, during the sample division into the experimental groups $\left(\mathrm{BAC}^{+}\right.$and $\mathrm{BAC}^{-}$ ), eight mammary quarters needed to be excluded from the study because they had only one bacterial isolation, making it impossible to perform appropriate statistical tests. Thus, 302 samples were evaluated for bacteriological examination (151 samples in the $\mathrm{BAC}^{+}$group and 151 samples in the BAC- group, between weeks -3 to +3$), 303$ physical evaluations of the mammary quar- ters $\left(152\right.$ in the $\mathrm{BAC}^{+}$group and 151 in the $\mathrm{BAC}^{-}$group, between weeks -3 to +3$), 128$ samples for CMT (63 in the $\mathrm{BAC}^{+}$group and 65 in the $\mathrm{BAC}^{-}$group, between weeks +1 to +3 ), and 174 samples for MSCC ( 86 in the $\mathrm{BAC}^{+}$group and 88 in the $\mathrm{BAC}^{-}$group, between the week of calving to the week +3 ).

Overall infection rate during transitional period was $25.82 \%$ (78/302), considering all mammary quarters evaluated between weeks -3 and +3 . Mixed infections and those with a single bacterial agent were observed in $2.64 \%$ (8/302) and $23.17 \%$ (70/302) of the samples, respectively. Non-aureus Staphylococci (NAS) was isolated from $69.2 \%(54 / 78)$ of the total positive samples for bacteriological examination $(\mathrm{n}=$ 78); $10.3 \%$ (8/78) was Corynebacterium spp., $6.4 \%$ (5/78) was Streptococcus spp., 3.8\% (3/78) was Serratia marcescens, and $10.3 \%$ (8/78) comprised associations between different microorganisms.

Distribution of bacterial isolates in each week of the transitional period revealed a maximum peak immediately after calving $(33.3 \%, 16 / 48)$, with NAS being the main agent isolated. On the other hand, the second week postpartum (+2) was characterized by a lower infection rate $(7.7 \%, 4 / 52)$. For other studied moments (weeks -3 , $-2,-1,+1$ and +3 ), frequencies of bacterial isolates were $27.1 ; 23.1 ; 25.5 ; 21.2$ and $17.3 \%$, respectively.

The effect of the group $\left(\mathrm{BAC}^{+}\right.$and $\left.\mathrm{BAC}^{-}\right)$, evaluated weeks $(-3$ to +3$)$, and interaction between groups and weeks on the physical parameters of the mammary gland, besides the odds ratio are presented in Table 1 . The parameters generalized volume alteration, elasticity of the skin, and increase in temperature of the mammary gland differed between the experimental groups ( $P=0.001 ; 0.011$ and 0.003 , respectively), with the highest frequencies occurring in the $\mathrm{BAC}^{-}$. Evaluation of the effect of time (weeks) on the physical parameters revealed higher frequencies in the $\mathrm{BAC}^{-}$group for generalized volume alteration $(P=0.001)$, localized volume alteration $(P=0.044)$, asymmetry $(P=0.001)$, reddish coloration of the mammary gland $(P=0.019)$, decreased elasticity $(P=0.001)$, increased temperature ( $P=0.001)$, swollen consistency of the mammary gland $(P=0.001)$, and altered consistency of the teats $(P=$ $0.001)$. No significant differences were observed when the interaction between groups and time was evaluated. The strip cup test was positive for only one mammary quarter at weeks +1 and +2 ( $\mathrm{BAC}^{+}$group), setting as the only positive samples for clinical mastitis. 
J.S. Ramos, K.M. Madureira, V.A.P. Baldacim, et al. 2020. Physiological and Pathological Alterations in the Mammary Gland of Holstein Cows during Transition Period. Acta Scientiae Veterinariae. 48: 1750.

Table 1. Results of the physical examination of mammary gland of cows during the transition period.

\begin{tabular}{|c|c|c|c|c|c|c|c|c|}
\hline \multirow{2}{*}{ Paramete } & & \multirow{2}{*}{$\mathrm{BAC}^{+}$} & \multirow{2}{*}{$\mathrm{BAC}^{-}$} & \multirow{2}{*}{$\mathrm{OR}^{1}$} & \multirow{2}{*}{$\mathrm{CI}(95 \%)$} & \multicolumn{3}{|c|}{ Effects } \\
\hline & & & & & & Week (W) & Group (G) & W x G \\
\hline \multirow{2}{*}{ Generalized V. } & Changed & $23(35 / 152)$ & $45.7(69 / 151)$ & 0.245 & $0.134-0.447$ & $0.000^{*}$ & $0.000 *$ & 0.944 \\
\hline & Normal & $77(117 / 152)$ & $54.3(82 / 151)$ & & & & & \\
\hline \multirow{2}{*}{ Localized V. } & Changed & $3.3(5 / 152)$ & $4.6(7 / 151)$ & 0.69 & $0.170-2.797$ & $0.044 *$ & 0.604 & 0.959 \\
\hline & Normal & $96.7(147 / 152)$ & $95.4(144 / 151)$ & & & & & \\
\hline \multirow{2}{*}{ Asymmetry } & Changed & $27.6(42 / 152)$ & $31.8(48 / 151)$ & 0.829 & $0.486-1.413$ & $0.000 *$ & 0.49 & 0.687 \\
\hline & Normal & $72.4(110 / 152)$ & $68.2(103 / 151)$ & & & & & \\
\hline \multirow{2}{*}{ Color } & Reddish & $2.0(3 / 152$ & $8(12 / 150)$ & 0.372 & $0.074-1.859$ & $0.019^{*}$ & 0.228 & 0.342 \\
\hline & Normal & $98(149 / 152)$ & $92(138 / 150)$ & & & & & \\
\hline \multirow{2}{*}{ Elasticity } & Decreased & $61.8(94 / 152$ & $74.2(112 / 151)$ & 0.474 & $0.259-0.868$ & $0.000 *$ & $0.011 *$ & 0.092 \\
\hline & Normal & $38.2(58 / 152)$ & $25.8(39 / 151)$ & & & & & \\
\hline \multirow{2}{*}{ Temperature } & Increased & $19.7(30 / 152$ & $32.5(49 / 151)$ & 0.349 & $0.173-0.703$ & $0.000 *$ & $0.003^{*}$ & 0.509 \\
\hline & Normal & $80.3(122 / 152)$ & $67.5(102 / 151)$ & & & & & \\
\hline \multirow{3}{*}{ Consistency } & Swollen & $46.7(71 / 152)$ & $53(80 / 151)$ & 0.430 & $0.181-1.020$ & $0.001 *$ & 0.291 & 0.373 \\
\hline & Firm & $17.1(26 / 152)$ & $17.2(26 / 151)$ & 0.939 & $0.398-2.214$ & & & \\
\hline & Normal & $36.2(55 / 152)$ & $29.8(45 / 151)$ & & & & & \\
\hline \multirow{2}{*}{ Injuries } & Present & $3.9(6 / 152)$ & $7.3(11 / 151)$ & 0.541 & $0.192-1.527$ & 0.629 & 0.246 & 0.419 \\
\hline & Absent & $96.1(146 / 152)$ & $92.7(140 / 151)$ & & & & & \\
\hline \multirow{3}{*}{ Lymph nodes } & Increased (1) & $27.6(42 / 152)$ & $20.5(31 / 151)$ & 0.544 & $0.235-1.260$ & 0.387 & 0.453 & 0.908 \\
\hline & Increased (2) & $13.8(21 / 152$ & $30.5(46 / 151)$ & 1.508 & $0.652-3.488$ & & & \\
\hline & Normal & $58.6(89 / 152)$ & $49(74 / 151)$ & & & & & \\
\hline \multirow{2}{*}{ Injuries - teats } & Present & $25(38 / 152)$ & $19.9(30 / 151)$ & 1.344 & $0.777-2.324$ & 0.132 & 0.29 & 0.886 \\
\hline & Absent & $75(114 / 152)$ & $80.1(121 / 151)$ & & & & & \\
\hline \multirow{2}{*}{ Supernumerary teat(s) } & Present & $0(0 / 152)$ & $4.6(7 / 151)$ & - & - & - & - & - \\
\hline & Absent & $100(152 / 152)$ & $95.4(143 / 151)$ & & & & & \\
\hline \multirow{3}{*}{ Consistency - teat(s) } & Thelitis & $0.7(1 / 152)$ & $2.6(4 / 151)$ & 0.430 & $0.181-1.020$ & $0.001 *$ & 0.291 & 0.373 \\
\hline & Cisternitis & $3.3(5 / 152)$ & $3.3(5 / 151)$ & 0.939 & $0.398-2.214$ & & & \\
\hline & Normal & $96.1(146 / 152)$ & $94(142 / 151)$ & & & & & \\
\hline
\end{tabular}

$* P<0.05$ by test GEE; Generalized V.= Generalized volume; Localized V.= Localized volume; ${ }^{1} \mathrm{OR}=$ Odds ratio, $95 \%$ confidence interval $(\mathrm{CI})$.

According CMT, differences were observed between groups $(P=0.021)$, with a higher frequency of positive tests in the $\mathrm{BAC}^{+}(36.5 \%, 23 / 63)$ compared to $\mathrm{BAC}^{-}(18 \%, 12 / 65) . \mathrm{BAC}^{+}$group had a greater chance of presenting a positive result during transition period ( $\mathrm{OR}=2,585,95 \% \mathrm{CI}=1,153-5,797)$. However, time and interaction between time and groups were not significant for CMT ( $P=0.560$ and 0.640 , respectively).

MSCC varied between studied weeks $(P=$ $0.001)$, between groups $(P=0.001)$, and between interaction of the two variables $(P=0.019)$. Highest median value of MSCC was observed at the calving week (1.5 $\times 10^{6}$ cells $/ \mathrm{mL}$, minimum value $=0.24 \times 10^{6}$ cells $/ \mathrm{mL}$ and maximum value $=59.0 \times 10^{6}$ cells $/ \mathrm{mL}$ ) being different $(P=0.001)$ from the weeks $+1,+2$, and +3 . The lowest median value $\left(0.08 \times 10^{6}\right.$ cells $/ \mathrm{mL}$, minimum value $=0.007 \times 10^{6}$ cells $/ \mathrm{mL}$ and maximum value $=$
$19,0 \times 10^{6}$ cells $/ \mathrm{mL}$ ) was observed in +3 , compared to all previous weeks $(P<0.05)$ [Figure 1]. Comparing groups, in the postpartum period, the $\mathrm{BAC}^{+}$had median values of $5.0 \times 10^{5}$ cells $/ \mathrm{mL}$ (minimum value $=0.07 \times$ $10^{5}$ cells $/ \mathrm{mL}$ and maximum value $=30.4 \times 10^{6}$ cells $/$ $\mathrm{mL}$ ), while the BAC ${ }^{-}$group had cell counts equivalent to $2.87 \times 10^{5}$ cells $/ \mathrm{mL}$ (minimum value $=0.23 \times 10^{5}$ cells $/ \mathrm{mL}$ and maximum value $=59.2 \times 10^{6}$ cells $/ \mathrm{mL}$ ).

\section{DISCUSSION}

This study evaluated physiological and pathological changes occurred in the mammary gland and milk examination of Holstein cows during transition period. To our knowledge, there are no published studies addressing the differentiation between physiological and pathological edema of the mammary gland, which directly aids in the diagnosis of clinical mastitis. 




Figure 1. Median values of somatic cell count (SCC) of milk from BAC ${ }^{+}$ and $\mathrm{BAC}^{-}$Holstein cows in postpartum period.

Overall rate of mammary infection for the transitional period was $25.82 \%$. NAS were predominantly isolated in the mammary secretion of cows during peripartum $(69.2 \%)$, similar to the frequency of $76.92 \%$ observed by Reis et al. [17] in the same property selected for the present research, while Odenstsen et al. [15] found frequencies of $31.7 \%$, indicating that sanitary management of the property directly impacts the rates and type of bacterial agents that cause mammary infections.

NAS bacteria are commonly found in the skin and canal of the teat and are associated with subclinical mastitis [20]; this aspect was verified in the present study, since of the 78 positive samples in the bacteriological examination, only one presented a positive result in the strip cup test. A previous study showed that some factors are associated with NAS infections, such as primiparous cows and a history of high SCC in cows [16].

Cows evaluated in the present study were treated during the dry period with a commercial product containing antibiotics and corticoid ${ }^{1}$. However, although dry cow therapy was used to prevent new occurrence of intramammary infection between the dry period and subsequent onset of lactation [23], this was not sufficient to avoid bacterial growth occurring during the transition period. The antimicrobials present in the formulation of commercial product are broad-spectrum, but probable failures in milking management and resistance to antimicrobials may have compromised the effectiveness of dry cow therapy [19].

The peak of mammary infection was observed on the day of parturition (33.3\%); the cortisol peak occurred due to the stress of calving, combined with the negative energy balance of the transition period, resulting in a stress leucogram and probable decrease in the functional activity of immune cells [7]. In addition to changes in immunity, physiological changes in the mammary gland itself such as increased volume, increased skin tension, and pendulous udders are risk factors for intramammary infection [12].

Circulatory changes occur with the proximity of calving, increasing blood flow to the mammary gland necessary for the production of colostrum. This event occurs weeks before calving and ceases abruptly on calving under hormonal influences [1]. These phenomena justify the changes observed in the physical examination of the mammary gland of cows belonging to $\mathrm{BAC}^{-}$group, such as generalized or localized increase in mammary gland volume, asymmetry, reddish coloration, decrease in skin elasticity, increase in temperature, and swollen consistency, which are compatible with the postpartum mammary gland physiological edema observed in $95 \%$ of the cows [10].

The intensity of the physiological edema of the mammary gland can vary according to the severity of the changes, and can be classified in scales varying from 1 to 5 [3] or from 1 to 10 [22]. The presence of positive Godet signal is observed in edema, which mainly accompanies enlargement of the mammary gland, decrease in skin elasticity, and increase in temperature; these parameters were altered during the study period for the $\mathrm{BAC}^{-}$group.

Mammary edema may also vary according to number of lactations, race, and season of the year; however, few studies have demonstrated changes in physical parameters during transition period, in terms of the differentiation between physiological and pathological edema $[3,10]$.

On the other hand, infection in the mammary quarters of cows belonging to the $\mathrm{BAC}^{+}$group promoted a decrease in the frequencies of increased volume, decreased elasticity, and elevated temperature of the mammary gland and may be associated with functional loss of the mammary parenchyma or persistent infectious process, characterizing the clinical findings of pathological changes in the mammary gland during the transition period.

Some studies have demonstrated the impact of infection on the health of mammary gland, such as changes in physical characteristics of the milk, damage 
to the mammary epithelial cells, and gene expression in these tissues $[9,18]$. Fundamental in the regulation of immune response, endothelial cells of mammary gland exert major changes in episodes of mammary infection, facilitating the passage of leukocytes and changing blood flow, factors that are directly associated with loss of mammary tissue [18]. Other impacts such as expression of genes in cases of infection of mammary gland have been studied, indicating that levels of expression depend on the duration of infection and type of bacteria [9].

Mammary quarters of the $\mathrm{BAC}^{+}$group presented higher percentages of positive reactions to CMT in weeks +1 and +2 , in addition to higher MSCC values. These milk test results show that the increases in these parameters are associated with the infection of the mammary gland, indicating differences between groups.

The result obtained for MSCC of colostrum in the present study $\left(1.5 \times 10^{6}\right.$ cells $\left./ \mathrm{mL}\right)$ differed from the values of $0.88 \times 10^{6}$ cells $/ \mathrm{mL}$ observed by Gomes et al. [6]. The status of mammary healthiness and bacterial infection rate were responsible for the observed differences.

MSCC was higher in the colostrum compared to weeks $+1,+2$, and +3 . The decrease in the MSCC in the first week postpartum has also been reported by Mehrzad et al. [11]. In the present study, low milk cellularity between weeks +1 to +3 is compatible with the low rate of mammary infection observed in the respective weeks. Accumulation of leukocytes during the colostrogenesis process and desquamation of the epithelial lining cells of mammary gland may be responsible for the high cellularity of colostrum. However, as milking progresses, the elimination of these cells, bacteria, and cellular debris accumulated in the mammary secretion and a subsequent decrease in milk cellularity occur. Physiological changes in cellularity in the immediate postpartum compromise the use of the MSCC for the detection of mastitis [17].
In general, the $\mathrm{BAC}^{+}$group presented a lower percentage in the frequencies of increased volume, decrease elasticity, elevated temperature of the mammary gland, and higher value of CMT, MSCC, and bacterial infection rate compared to the $\mathrm{BAC}^{-}$group. These phenomena are probably related to the histological characteristics of the mammary tissue, associated with the chronic inflammatory process in the group of cows with mammary infection manifested during the transition period.

\section{CONCLUSIONS}

In this study we characterized physiological and pathological alterations in mammary gland and we observed during the physical examination higher frequencies of parameters such as generalized or localized alteration in volume, asymmetry, reddish coloration, decreased elasticity of the skin, increased temperature and swollen consistency in cows free of mammary infection and carriers of postpartum physiological edema. In the $\mathrm{BAC}^{+}$group, a lower frequency was observed for changes in volume, elasticity, and temperature, higher frequencies of samples positive for CMT test and higher cellularity, which are characteristics compatible with pathological alterations. This study contributes to the diagnosis of mastitis during the transition period through physical examination of the mammary gland and evaluation of its secretion.

\section{MANUFACTURER}

${ }^{1}$ MSD Animal Health, Boxmeer, Netherlands.

Funding. This research was supported by grants from National Counsil for Cientific and Technological Development (CNPq; Project number 479381/2013).

Ethical approval. The Animal Ethics Committee of the Faculty of Veterinary Medicine and Animal Science of the University of São Paulo - FMVZ/USP approved this research (protocol \# 2767/2012).

Declaration of interest. The authors report no conflicts of interest. The authors alone are responsible for the content and writing of paper.

\section{REFERENCES}

1 Barrington G.M., McFadden T.B., Huyler M.T. \& Besser T.E. 2001. Regulation of colostrogenesis in cattle. Livestock Production Science. 70(1): 95-104.

2 Brandon M., Watson D. \& Lascelles A. 1971. The mechanism of transfer of immunoglobulin into mammary secretion of cows. Australian Journal of Experimental Biology and Medical Scienc. 49: 613-623.

3 Dentine M.R. \& McDaniel B.T. 1983. Variation of edema scores from herd-year, age, calving month and sire. Journal of Dairy Science. 66(11): 2391-2399. 
4 Godden S.M., Smolenski D.J., Donahue M., Oakes J.M., Bey R., Wells S., Sreevatsan S. \& Stabel J. 2012. Heattreated colostrum and reduced morbidity in preweaned dairy calves: results of a randomized trial and examination of mechanisms of effectiveness. Journal of Dairy Science. 95(7): 4029-4040.

5 Gomes V., Madureira K.M., Soriano S., Della Libera A.M.M.P., Blagitz M.G. \& Benesi F.J. 2011. Factors affecting immunoglobulin concentration in colostrum of healthy Holstein cows immediately after delivery. Pesquisa Veterinária Brasileira. 31(1): 53-56.

6 Gomes V., Madureira K.M., Della Libera A.M.M.P., Blagitz M.G., Alves M., Baptistella F. \& Benesi F.J. 2011. Dinâmica da celularidade do colostro de vacas da raça Holandesa no pós-parto imediato. Arquivo Brasileiro de Medicina Veterinária e Zootecnia. 63(5): 1054-1059.

7 Gomes V., Miranda M.S., Sousa R.S., Fagliari J.J. \& Madureira K.M. 2017. Imunidade celular em vacas Holandesas soropositivas para o Vírus da Leucose Bovina (BLV) durante o período de transição. Arquivo Brasileiro de Medicina Veterinária e Zootecnia. 69(6): 1367-1375.

8 Grunert E. 1993. Sistema genital feminino. In: Dirksen G., Gründer H.D. \& Stöber M. Rosenberger (Eds). Exame Clínico dos Bovinos. Rio de Janeiro: Guanabara Koogan, pp.269-314.

9 Kościuczuk E.M., Lisowski P., Jarczak J., Krzyżewski J., Zwierzchowski L. \& Bagnicka E. 2014. Expression patterns of $\beta$-defensin and cathelicidin genes in parenchyma of bovine mammary gland infected with coagulase-positive or coagulase-negative Staphylococci. BMC Veterinary Research. 10(1): 246.

10 Melendez P., Hofer C.C. \& Donovan G.A. 2006. Risk factors for udder edema and its association with lactation performance on primiparous Holstein cows in a large Florida herd, U.S.A. Preventive Veterinary Medicine. 76(3-4): 211-221.

11 Mehrzad J., Dosogne H., Meyer E., Heyneman R. \& Burvenich C. 2001. Respiratory burst activity of blood and milk neutrophils in dairy cows during different stages of lactation. Journal of Dairy Research. 68(3): 399-415.

12 Montero A.S. 2013. Edema de ubre en ganado bovino: I entrega. Nutrición Animal Tropical. 7(1): 25-39.

13 National Mastitis Council. 1999. Laboratory Handbook on Bovine Mastitis. Madison: NMC, 222 p.

14 Neville M.C., McFadden T.B. \& Forsyth I. 2002. Hormonal regulation of mammary differentiation and milk secretion. Journal of Mammary Gland Biology and Neoplasia. 7(1): 49-66.

15 Odensten M.O., Berglund B., Persson Waller K. \& Holtenius K. 2007. Metabolism and udder health at dry-off in cows of different breeds and production levels. Journal of Dairy Science. 90: 1417-1428.

16 Oliveira C.S.F, Hogeveen H., Botelho A.M., Maia P.V., Coelho S.G. \& Haddad J.P.A. 2015. Cow-specific risk factors for clinical mastitis in Brazilian dairy cattle. Preventive Veterinary Medicine. 121(3-4): 297-305.

17 Reis J.F., Leite R.F., Silva C.P.C., Baccili C.C., Melville P.A., Benites N.R. \& Gomes V. 2016. Somatic cell counts as an indicator of mammary infection in periparturient cows. Brazilian Journal of Veterinary Research and Animal Science. 53(2): 161-168.

18 Ryman V.E., Packiriswamy N. \& Sordillo L.M. 2015. Role of endothelial cells in bovine mammary gland health and disease. Animal Health Research Reviews. 16(2): 135-149.

19 Rupp R. \& Boichard D. 2003. Genetics of resistance to mastitis in dairy cattle. Veterinary Research. 34(5): 671-688.

20 Santos L.L.D., Costa G.M.D., Pereira U.D.P., Silva M.A. \& Silva N.D. 2011. Mastites clínicas e subclínicas em bovinos leiteiros ocasionadas por Staphylococcus coagulase-negativa. Revista do Instituto Adolfo Lutz. 70(1): 1-7.

21 Schalm O.W. \& Noorlander D.D. 1957. Experiments and observations leading to development of the California Mastitis Test. Journal of American Veterinary Medical Association. 130: 199-204.

22 Tucker W.B., Adams G.D., Lema M., Aslam M., Shin I.S., Le Ruyet P. \& Weeks D.L. 1992. Evaluation of a system for rating edema in dairy cattle. Journal of Dairy Science. 75(6): 2382-2387.

23 van Hoeij R.J., Lam T.J.G.M., Koning D.B., Steeneveld W., Kemp B. \& van Knegsel A.T.M. 2016. Cow characteristics and their association with udder health after different dry period lengths. Journal of Dairy Science. 99(10): 8330-8340. 